ALSO IN THIS SECTION

Vatican Council debates agbiotech p4

UK to pursue contract clinical trials p5

Cancer trials get set for biomarkers $\mathrm{p} 6$

News in brief p11

News Feature: Signal transduction inhibitors p15

\title{
China approves first gene therapy
}

China became the first country to approve the commercial production of a gene therapy, and it is due to hit the market in early January. Despite technical hurdles and the wary attitude of regulatory authorities outside China, other countries are expected to soon follow suit.

On October 16, 2003, Shenzhen SiBiono GenTech (Shenzhen, China), obtained a drug license from the State Food and Drug Administration of China (SFDA; Beijing, China) for its recombinant Ad-p53 gene therapy for head and neck squamous cell carcinoma (HNSCC) - a cancer that accounts for about $10 \%$ of the 2.5 million annual new cancer patients in China. Sold under the brand name Gendicine, the world's first commercial gene therapy uses an adenoviral vector and cost the company more than RMB $80 \quad(\$ 9.6)$ million to develop in addition to research grants they received from government.

"We have had more than five years of clinical trials, and the only side effect of Gendicine is self-limited fever," says Zhaohui Peng, chairman and CEO of SiBiono. After eight weeks of a joint treatment of radiotherapy and weekly gene therapy injections, $64 \%$ of late-stage HNSCC tumors experienced complete regression and $32 \%$ experienced partial regression.
"SiBiono's approach is not a trivial one," Jean-François Carmier, CEO of Transgene (Strasbourg, France) comments. "Introgen has been using a similar strategy for head and neck cancer and their product is showing encouraging results in Phase 3 trials" (see Table 1).

The success of SiBiono was in overcoming difficulties in developing the right system for delivering its adenoviral vector-considered an effective way of introducing a gene into tumor cells-without integrating the gene in the host cells' chromosomes and creating genetic alterations. SiBiono has addressed safety concerns by carefully

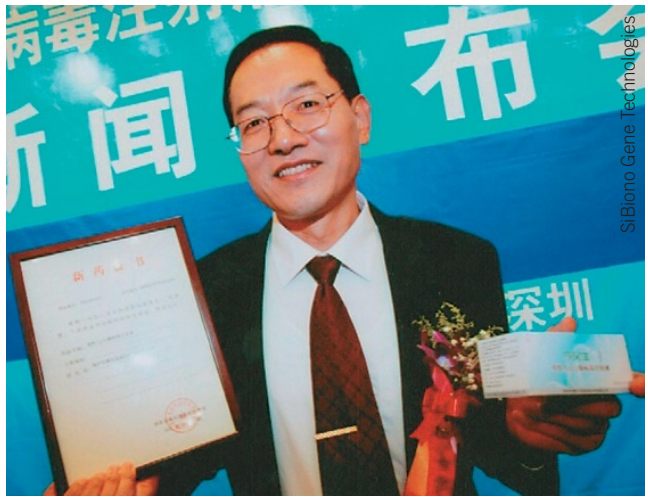

Zhaohu Peng receives an approval certificate issued by China's State Food and Drug Administration for Gendicine, the world's first commercial gene therapy. dosing the injection (injecting a weekly dose of $1 \times 10^{12}$ viral particles) and closely monitoring reactions of participants during the clinical trials and subsequently following up with them for one to five years, according to Peng.

So why did the first commercial gene therapy treatment get produced and approved in China? "In China, where hundred of thousands die of diseases such as cancer without access to the clinical options available to patients in the US and Europe, the potential for a one-time treatment that is relatively simple to administer is very appealing," says Mark Kay, a director of the human gene therapy program at Stanford University (Stanford, CA, USA). Size matters as well. "Due to its large population, the Chinese can recruit enough patients for a trial in a short time and can therefore generate statistically significant amounts of clinical data very rapidly," says Carmier.

And because China has not been blighted by failure-as happened in the United States with the death of Jesse Gelsinger of an inherited nitrogen metabolism disorder

\begin{tabular}{|c|c|c|c|c|}
\hline Company or research institute & Indication & Delivered gene & Vector & $\begin{array}{l}\text { Phase of clinical } \\
\text { development }\end{array}$ \\
\hline $\begin{array}{l}\text { Shenzhen SiBiono Gene } \\
\text { Technologies (Shenzhen, China) }\end{array}$ & HNSCC & Tumor protein p53 & Adenovirus & Approved \\
\hline $\begin{array}{l}\text { Shanghai Sunway Biotech } \\
\text { (Shanghai, China) }\end{array}$ & HNSCC & HAdv5 oncolytic virus & Adenovirus & Phase 3 \\
\hline AnGes MG (Osaka, Japan) & Arteriosclerosis obliterans & Hepatocyte growth factor & Plasmid & Phase2 \\
\hline $\begin{array}{l}\text { GenVec, Inc. } \\
\text { (Gaithersburg, MD, USA) }\end{array}$ & Pancreatic, esophageal and rectal cancers & Human tumor necrosis factor-? & Adenovirus & Phase 2 \\
\hline $\begin{array}{l}\text { Introgen } \\
\text { (Austin, TX, USA) }\end{array}$ & $\begin{array}{l}\text { Head and neck, lung, breast, esophageal, } \\
\text { ovarian, bladder, brain, prostate and } \\
\text { bronchoalveolar cancers }\end{array}$ & Tumor protein p53 & Adenovirus & Phases 1-3 \\
\hline Transgene (Strasbourg, France) & Cervical cancer & $\begin{array}{l}\text { Human papilloma virus type } 16 \text { E6 and } \\
\text { E7 antigens and interleukin } 2\end{array}$ & Vaccinia virus & Phase 2 \\
\hline Transgene (Strasbourg, France) & Breast, lung, prostate and renal cancers & Human mucin 1 antigen and interleukin 2 & Vaccinia virus & Phase 2 \\
\hline
\end{tabular}


(Nat. Biotechnol. 18, 1136 2000) and more recently in Europe with the X-linked, severe combined immunodeficiency syndrome trials (Nat.Biotechnol. 21, 121, 2003)-the Chinese regulatory authorities may be more receptive to the technology.

But some suggest that the regulatory process is much more lax in China than elsewhere. "The recently approved gene therapy in China had only 120 people in clinical trials, whereas the same therapy in the US has hundreds of people and yet it has not been approved," says Hitoshi Kotani, senior vice president of gene therapy firm AnGes MG (Osaka, Japan).

But Peng refutes Genedicine was approved because of the allegedly looser regulation of the Chinese authorities, a sentiment that is echoed by Peng Shang, vice director of cell engineering research center at the Fourth Military Medical University (Xi'an, China). "In fact, the SFDA had a routine practice not to approve any new kind of medicine if the kind of drug was not authorized by the US FDA," Shang says. Peng has been lobbying SFDA for years and the agency gradually changed its attitude since early this year, as shown by the approval of the new gene therapy and, on November 22, by giving a green light to clinical trails for a new SARS vaccine developed by Sinovac (Beijing).

Many scientists involved in gene therapy say there are no major regulatory issues in the US and Europe preventing gene therapy trials from getting the go ahead. Massimo Cristofanilli, associate professor at the University of Texas M.D. Anderson Cancer Center, (Houston), a principle investigator of Introgen's Advexin to treat breast cancer, agrees: "The process for getting gene therapy into clinic in the US is conservative. The concerns with safety are stringent but also fair."

By comparison, clinical trials for gene therapy in Japan could take longer than a regular treatment. The Ministry of Health, Labor and Welfare (Tokyo, Japan) requires A "confirming application" (referring to basic quality of the medicine and results of animal experiments) in addition to the standard application for clinical trials. And healthy humans usually won't take part in phase 1 clinical trials because of the higher risk involved with an experimental therapy.

Whatever the reason China was first to approve a gene therapy, this success story can only help make the technology become more accepted.

Joint reporting from Sue Pearson, Hitchin, UK; Hepeng Jia, Beijing; and Keiko Kandachi, Tokyo

\section{Vatican debates agbiotech}

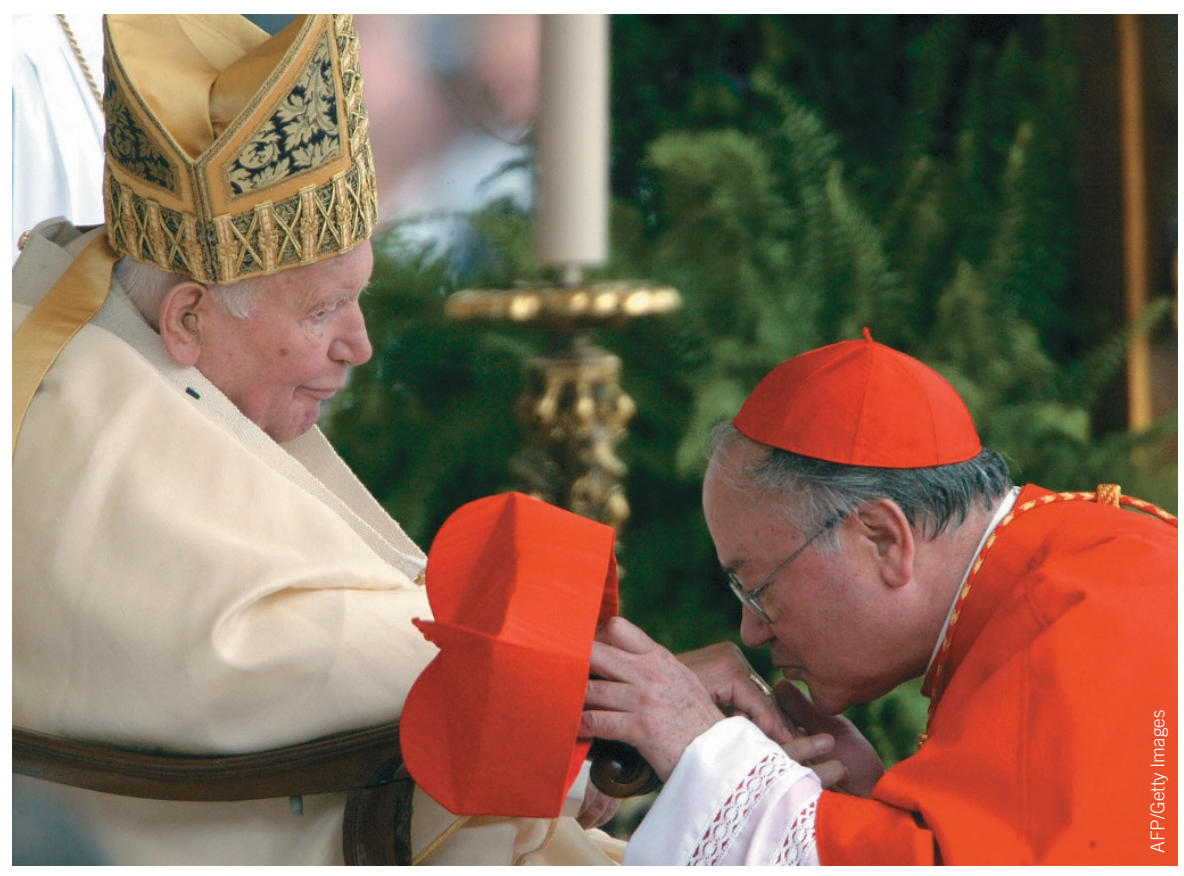

Catholic Cardinal Renato Raffaele Martino is expected to ask the Vatican to bless GM crops

Cardinal Renato Martino and other key Vatican officials seem poised to endorse the use of genetically modified (GM) crops. However, by the end of a seminar, "GMO: threat or hope," convened by the Pontifical Council of Justice and Peace in Rome on November 10-11, he and several fellow officials cautiously sidestepped taking a definitive stance, insisting that they are in the preliminary stage of gathering information on this "difficult issue," while also maintaining that this technology "should not be abandoned."

"The Vatican is not monolithic...but it plays an enormous role as a moral voice," says Val Giddings, vice president with the Biotechnology Industry Organization (Washington, DC, USA), who met in 2003 with several Vatican officials to discuss the use of GM crops. The council's potential influence over the acceptance of GM crops would be "significant and formidable," wherever there are substantial Catholic populations, such as the Philippines, throughout Latin America and parts of Africa, says Giddings. Already, the positive inclinations of Cardinal Martino and others toward GM crops are having salutary effects in these regions, he adds. "I don't think it's a tidal wave of influence, but a substantial diffusion... and very important."
Unlike other major religions, the Catholic Church's highly centralized, hierarchical authority in the Vatican gives it a unique position to influence a tremendous number of people. "Many religious traditions have decentralized authority structures where policies take a local, regional or national form," says Leigh Turner, an ethicist from McGill University (Montreal) who is currently with the Institute for Advanced Study (Princeton, NJ, USA). For example, the Indonesian Ulemas Council (Jakarta) endorsed GM crops in July 2003-a ruling that applies only within that nation.

The recent stirrings within the council appear to be triggered in no small part by Cardinal Martino's personal interest in GM organisms following his 16-year tenure as Vatican ambassador to the United Nations. He stated several times that he consumed many GM foods without ill effect during his years in New York, admitting that this evidence of safety is anecdotal. In a more serious tone, he wonders aloud whether this new technology could help to address widespread hunger in developing countries. But views about GM crops are far from uniform within the Catholic Church.

For example, the Pontifical Academy of Sciences in a 2001 report declared it a "moral imperative" that the "fruits of all new technologies be made available to all the 